\title{
Analysis of Environmental Health Risk Exposure to Heavy Metals in Communities that Consume the BatissaViolaceacelebensis from Konaweha River, Indonesia
}

\author{
Erwin Azizi Jayadipraja ${ }^{1}$, Solihin Solihin ${ }^{2}$, Muhammad Chaerul ${ }^{3}$, \\ Ramadhan Tosepu ${ }^{4}$ \\ \{erwinazizijayadipraja@gmail.com ${ }^{1}$ \} \\ 1,2 College of Mandala Waluya Health School, Kendari, Indonesia \\ ${ }^{3}$ Fajar University, Makassar, Indonesia \\ ${ }^{4}$ Faculty of Public Health, Halu Oleo University Kendari, Indonesia
}

\begin{abstract}
Batissaviolaceacelebensisis an endemic species of shellfish on Sulawesi Island. This animal is one of the staple foods of the people living around the Konaweha River. Various researches have been conducted to find the contamination of Cadmium, Plumbum and Hydragryrum heavy metals on the Konaweha River. Heavy metals can cause bioaccumulation in Batissaviolaceacelebensis. The objective of this study was to analyze the environmental health risks of heavy metals exposure in humans who consumed Batissaviolaceacelebensisfrom the Konaweha River. The study employed quantitative research (Field Research and Research Laboratory). By using the Environmental Health Risk Analysis method adopted from USEPA. The results showed that the concentration of heavy metals in Batissaviolaceacelebensis was $0.03345 \mathrm{mg} / \mathrm{kg}(\mathrm{cd}), 0.04505 \mathrm{mg} / \mathrm{kg}(\mathrm{Pb})$ and $0.001833 \mathrm{mg} / \mathrm{kg}(\mathrm{Hg})$. The value of human intakes is $0.0054235 \mathrm{mg} / \mathrm{kg} / \mathrm{day}(\mathrm{cd}), 0.0073076$ $\mathrm{mg} / \mathrm{kg} /$ day $(\mathrm{Pb})$ and $0,0002962 \mathrm{mg} / \mathrm{kg} /$ day $(\mathrm{Hg})$. The duration of exposure for 30 years, the average intake rate of 68.09 grams/day, the average exposure frequency is 124 days/year. So that the Risk Quotient value $<1$ is obtained. Pollution in the Konaweha River has contaminated Batissavoilecaecelebensis. It is predicted that the risk of contamination will be felt by humans if they consume more than 30 years. It would be better if the Risk Quotient value was lowered by minimizing the intensity of exposure to consumption of Batissaviolaceacelebensis.
\end{abstract}

Keywords: Environmental Health Risk Analysis, Batissaviolaceacelebensis, Cadmium, Plumbum, Hydragryrum, Indonesia.

\section{Introduction}

Pollution almost happens in all over the world and elements, such as air pollution that harms people's health [1] and water polution that implicates public health [2]. The contamination of heavy metals through aquatic ecosystem has become a problem in environmental health for several decades [3],[4]. The contamination of heavy metals in aquatic ecosystem intensively relates to the 
loose of heavy metals by domestic waste [5], industry [6] and another human activities. The contamination of heavy metals can make deadly effect towards marine organisms and effects the imbalance of ecologic and diversity of marine organisms [7]. Heavy metals like Mercury ( $\mathrm{Hg})$ is a type of heavy metals that has the most dangerous toxic effect like Lead $(\mathrm{Pb})$ and Cadmium $(\mathrm{Cd})$, they are known as the big three heavy metal with the highest toxicity level in human's health [8].

There is a Konaweha river in Southeast Sulawesi, this river is one of the supply of clean water source of the community and there is also typical food such as endemic biota namely 'pokea' (Batissaviolaceacelebensis Martens, 1897) [9],[10]. Based on the result of research in 2017, Konewaha river became light polluted category [11]. The existence of heavy metals in the environment causes accumulation in aquatic biota [12]. The more higher the heavy metals in neighborhood of shellfish, therefore shells body will accumulate heavy metals in high amount [13].

The exposure of heavy metals to animals and human can give acute toxic, sub acute, and chronic [14]. Chronic toxic effect happens if chemical materials accumulate in biological systems (absorption exceeds biotransformation excretion) or if it produces toxic effect that is not recovered or if it is not enough from the biological system to do the recovery from the damage of exposure frequency interval, or the exposure happens repeatedly [15]. Based on fact and theory, this study aims to know how big the impact to the health risk because the consumption of Batissaviolaceacelebensis Martens, 1897 that exposed heavy metals in Konaweha river.

\section{Method}

This study was as type of quantitative research (Field Research and Research Laboratory). This type of research was an observational analytic study with the design of Environmental Health Risk Analysis (ARKL) [16],[17] due to exposure to Cadmium (Cd), Plumbum (Pb) and Hydrargyrum $(\mathrm{Hg})$. The population of this study were people who live around Konaweha river that consume Batissaviolaceacelebensis Martens, 1897. The samples of this study were people with minium age (40 years). The sample Batissaviolaceacelebensis Martens, 1897 was taken from three locations in Konaweha river.

1st Location : $03^{0} 56^{\prime} 07.47^{\prime \prime}$ Sand $122^{\circ} 25^{\prime} 55.54^{\prime \prime} \mathrm{E}$

2nd Location : $03^{0} 56^{\prime} 26.48^{\prime \prime}$ Sand $122^{0} 25^{\prime} 42.92^{\prime \prime} \mathrm{E}$

3rd Location : $03^{0} 56^{\prime} 10.58^{\prime \prime}$ Sand $122^{0} 25^{\prime} 48.68^{\prime \prime} \mathrm{E}$

Then, those samples were tested to know heavy metals content in Forensic Biology Laboratory, Faculty of Mathematic and Sciences, Halu Oleo University by using destruction method and Atomic Absorption Spectrofotometer (AAS). The respondent's intake data were collected by using questionnaire and antropometry of respondent and they were measured by using height and weight measuring instruments with SNI standard.

\section{Result}

The result of concentration measurement of heavy metals Cadmium $(\mathrm{Cd})$, Plumbum, and Hydrargyrum (Hg) in 'pokea' (Batissaviolacecelebensis Martens, 1897) can be seen in Table 1. 
Table 1. Concentration of Heavy Metals Batissaviolacecelebensis Martens, 1897 from Konaweha river.

\begin{tabular}{ccccc}
\hline No. & Location & $\mathrm{Cd}(\mathrm{mg} / \mathrm{kg})$ & $\mathrm{Pb}(\mathrm{mg} / \mathrm{kg})$ & $\mathrm{Hg}(\mathrm{mg} / \mathrm{kg})$ \\
\hline 1 & 1st Location & 0.0387 & 0.0473 & 0.0014 \\
2 & 1st Location & 0.0317 & 0.0473 & 0.0014 \\
3 & 2nd Location & 0.0282 & 0.0473 & 0.0027 \\
4 & 2nd Location & 0.0387 & 0.0541 & 0.0014 \\
5 & 3rd Location & 0.0282 & 0.0405 & 0.0027 \\
6 & 3rd Location & 0.0352 & 0.0338 & 0.0014 \\
\hline & Average & 0.03345 & 0.04505 & 0.001833 \\
\hline
\end{tabular}

Based on the results of the calculation of similarities of Louvar \& Louvar (1998) as follows :

$$
\text { I) }(I)=\frac{\mathrm{C} \times \mathrm{R} \times \mathrm{fE} \times \mathrm{Dt}}{\mathrm{Wb} \times \mathrm{T}_{\mathrm{a}}}
$$

And Risk Level (RQ)

$$
R=\frac{l}{\text { Rfd or RFC }}
$$

The exposure of heavy metals $\mathrm{Cd}, \mathrm{Pb}$ and $\mathrm{Hg}$ on 97 respondents that consume 'pokea' (Batissaviolaceacelebensis Martens, 1897) from Konaweha river Morosi sub-district Konawe district can be seen in table 5.11, it shows that the respondents or communities who consume 'pokea' from Konaweha river do not have any health risks for at least 30 years later because RQ value for each heavy metals $(\mathrm{Cd}, \mathrm{Pb}$ and $\mathrm{Hb})$ are under 1 or $<1$. It can be assumed that heavy metals content $(\mathrm{Cd}, \mathrm{Pb}$ and $\mathrm{Hg})$ only focus on 'pokea' and the concentration value and other variables value are not change for 30 years later. Meanwhile, population calculation can be used variable distribution in table 2 .

\begin{tabular}{|c|c|c|c|c|c|c|c|c|}
\hline & & & & & & & & \\
\hline \multirow{2}{*}{ Value } & \multicolumn{3}{|c|}{ Heavy Metals Concentration (C) } & \multirow{2}{*}{$\begin{array}{c}\mathrm{R} \\
\text { (gr/day) }\end{array}$} & \multirow{2}{*}{$\begin{array}{c}\mathrm{fE} \\
\text { (day/year) }\end{array}$} & \multirow{2}{*}{$\begin{array}{l}\mathrm{Wb} \\
(\mathrm{kg})\end{array}$} & \multirow{2}{*}{ (Dt } & \multirow{2}{*}{ Tavg } \\
\hline & $\mathrm{Cd}$ & $\mathrm{Pb}$ & $\mathrm{Hg}$ & & & & & \\
\hline Mean & 0.01720 & 0.02317 & 0.00094 & 68.09 & 124 & 49.84 & \multirow{3}{*}{30} & \multirow{3}{*}{10950} \\
\hline Median & 0.01282 & 0.01727 & 0.00070 & 74 & 104 & 50 & & \\
\hline SD & 0.01427 & 0.01921 & 0.00078 & 23.58 & 71.82 & 11.45 & & \\
\hline
\end{tabular}

Table 2. Distribution of variable analysis of the risks of Batissaviolacecelebensis Martens, 


\begin{tabular}{l|c|c|c|c|c|c|c|c} 
Min & 0.00256 & 0.00345 & 0.00014 & 29.6 & 52 & 20 & & \\
Max & 0.07714 & 0.10389 & 0.00423 & 129.5 & 364 & 79 & & \\
CoV & 82.94 & 82.94 & 82.95 & 34.63 & 57.91 & 22.97 & & \\
\hline
\end{tabular}

Source : Primary Data, 2018

Based on the results of risk calculation, it shows that RQ value from three heavy metals $(\mathrm{Cd}$, $\mathrm{Pb}$ and $\mathrm{Hg}$ ) are $<1$. Therefore, it can be assumed that nowadays and 30 years later, communities who consume 'pokea' from Konaweha river,Morosi sub-district, Konawe district are still safe and it does not give any risk through heavy metals content $(\mathrm{Cd}, \mathrm{Pb}$, and $\mathrm{Hg})$ in 'pokea' (Batissaviolaceacelebensis Martens, 1897).

\section{Discussion}

The level of heavy metals pollution really determine the concentration of heavy metals in aquatic biota. Several researches show the level of heavy metals accumulation in aquatic biota. In Calang beach, it is found that several contents such as Lead $(\mathrm{Pb})$, Mercury $(\mathrm{Hg})$ and Cadmium (Cd) in first station are 6.93;0.71;2.54 mg/kg [18]. Another research showed that there were 29 fish species in South China Sea, they are ; 51-115.81 ng/g (Cd), 0.54-27.31 ng/g (Pb), 0.02-1.26 $\mu \mathrm{g} / \mathrm{g}(\mathrm{Cr}), 8.32-57.48 \mathrm{ng} / \mathrm{g}(\mathrm{Ni}), 0.12-1.13 \mu \mathrm{g} / \mathrm{g}(\mathrm{Cu}), 2.34-6.88 \mu \mathrm{g} / \mathrm{g}(\mathrm{Zn}), 2.51-22.99 \mu \mathrm{g} / \mathrm{g}(\mathrm{Fe})$, and $0.04-0.81 \mu \mathrm{g} / \mathrm{g}(\mathrm{Mn})$ [7]. Moreover, heavy metals are also identified in river, $\mathrm{Pb}, \mathrm{Cr}$ and $\mathrm{Zn}$ consentration in many fish samples exceed consumption limits [19], and it is contaminated by heavy metals in shrimp (Macrobrachiumrosenbergii and Penaeusmonodon) that are collected from Khulna-Satkhira area in Bangladesh with concentration; Pbthat is $(0.52-1.16 \mathrm{mg} / \mathrm{kg})$ and $\mathrm{Cd}$ that is $(0.05-0.13 \mathrm{mg} / \mathrm{kg})$ [20].

This study showed that there were heavy metals contents such as $\mathrm{Cd}, \mathrm{Pb}$ and $\mathrm{Hg}$ in Batissaviolaceacelebensis Martens, 1897 Konaweha river. Those heavy metals concentration were $\mathrm{Cd} 0.03345 \mathrm{mg} / \mathrm{L}, \mathrm{Pb} 0.04505 \mathrm{mg} / \mathrm{L}$ dan $\mathrm{Hg} 0.001833 \mathrm{mg} / \mathrm{L}$. Heavy metals can be concentrated through food chain and accumulated in organism that benthic such as bivalvia type. Bivalva grouphas been known that it can accumulate the types of pollutant until the most dangerous level for customers. It related to the feeder filter properties owned and the way they live their life that mostly settle, therefore, the possibility was small to eschew from the change of aquatic environmental which was dangerous. The result of risk analysis calculation of environmental health shows that RQ value was $<1$. Although, RQ value was $<1$, but by having concentration and bioaccumulation of heavy metals of $\mathrm{Cd}, \mathrm{Pb}$ and $\mathrm{Hg}$ in 'pokea' shells body, it is possible that in the future it will impact human health. It is because of industry development, people activities etc, that leads to the enhancement of water river pollution and shells (pokea). As mentioned before, heavy metals $(\mathrm{Cd}, \mathrm{Pb}$ and $\mathrm{Hg})$ are heavy metals with high toxicity.

Indonesian National Standardization Agency and USEPA has stipulate the standard/maximum value of shells consumption which is not more than $1.0 \mathrm{mg} / \mathrm{kg}$, Pbless than $1.5 \mathrm{mg} / \mathrm{kg}$ and $\mathrm{Hg}$ less than $1.0 \mathrm{mg} / \mathrm{kg}$. If heavy metals contents in those 'pokea' exist in shells with the concentration more than pre-termined value, it will give negative impact to the communities health who consume it. 
Risk management is a follow-up that must be done if the result of characterization shows that it is not safe risk level or unacceptable. Management or control of health risk is done by 3 approaches, they are technology approach, socio-economic approach and institutional approach. Control can be done by determining safety limit/low risk that happens by reducing contact from exposure such as minimize the consumption of Batissaviolaceacelebensis Martens, 1897 from Konaweha river.

\section{Conclusion}

The conclusions of this research areas follow :

1. Heavy metals concentration such as Cadmium $(\mathrm{Cd})$, Plumbum $(\mathrm{Pb})$ and Hydrargyrum $(\mathrm{Hg})$ in 'pokea' respectively are $0.03345 \mathrm{mg} / \mathrm{kg}, 0.04505 \mathrm{mg} / \mathrm{kg}$ and $0.001833 \mathrm{mg} / \mathrm{kg}$.

2. The amount of respondent 'sintake or average in take inconsuming 'pokea' for heavy metals Cadmium (Cd) is $0.0054235 \mathrm{mg} / \mathrm{kg} / \mathrm{day}$, Plumbum $(\mathrm{Pb})$ is $0.0073076 \mathrm{mg} / \mathrm{kg} / \mathrm{day}$ and Hydrargyrum $(\mathrm{Hg})$ is $0.0002962 \mathrm{mg} / \mathrm{kg} / \mathrm{day}$.

3. The level of respondent's risk and population is based on RQ calculation that is $<1$. It means that communities that consume 'pokea' from Konaweha river does not have risk of health problems for nowadays an 30 years later.

\section{References}

[1] E. A. Jayadipraja, A. Daud, and A. H. Assegaf, "Air Pollution and Lung Capacity of People Living around the Cement Industry," Public Health of Indonesia, vol. 2, pp. 76-83, 2016.

[2] G. Nabi, M. Ali, S. Khan, and S. Kumar, "The crisis of water shortage and pollution in Pakistan: risk to public health, biodiversity, and ecosystem," Environmental Science and Pollution Research, pp. 1-3, 2019.

[3] M. S. Islam, M. K. Ahmed, M. Raknuzzaman, M. Habibullah-Al-Mamun, and M. K. Islam, "Heavy metal pollution in surface water and sediment: a preliminary assessment of an urban river in a developing country," Ecological indicators, vol. 48, pp. 282-291, 2015.

[4] D. Paul, "Research on heavy metal pollution of river Ganga: A review," Annals of Agrarian Science, vol. 15, pp. 278-286, 2017.

[5] G. Kibria, M. M. Hossain, D. Mallick, T. C. Lau, and R. Wu, "Trace/heavy metal pollution monitoring in estuary and coastal area of Bay of Bengal, Bangladesh and implicated impacts," Marine pollution bulletin, vol. 105, pp. 393-402, 2016.

[6] N. Saha, M. S. Rahman, M. B. Ahmed, J. L. Zhou, H. H. Ngo, and W. Guo, "Industrial metal pollution in water and probabilistic assessment of human health risk," Journal of environmental management, vol. 185, pp. 70-78, 2017.

[7] Y.-G. Gu, Q. Lin, X.-H. Wang, F.-Y. Du, Z.-L. Yu, and H.-H. Huang, "Heavy metal concentrations in wild fishes captured from the South China Sea and associated health risks," Marine pollution bulletin, vol. 96, pp. 508-512, 2015.

[8] I. Shtepliuk, N. M. Caffrey, T. Iakimov, V. Khranovskyy, I. A. Abrikosov, and R. Yakimova, "On the interaction of toxic Heavy Metals $(\mathrm{Cd}, \mathrm{Hg}, \mathrm{Pb})$ with graphene quantum dots and infinite graphene," Scientific reports, vol. 7, p. 3934, 2017.

[9] S. N. Basri, B. Bahtiar, and L. Anadi, "Pertumbuhan, Mortalitas dan Tingkat Pemanfaatan Kerang Pokea (Batissa violacea var. celebensis von Martens, 1897) di Sungai Laeya Konawe 
Selatan Provinsi Sulawesi Tenggara," Jurnal Biologi Tropis, vol. 19, 2019.

[10] S. A. Rasyid, M. Bintang, B. P. Priosoeryanto, R. U. Nurlila, and R. A. Surya, "Analysis Chemical Compound of Pokea (Batissa Violacea Celebensis Martens 1897) The Origin of Konawe Regency Southeast Sulawesi," Indian Journal of Public Health Research \& Development, vol. 9, 2018.

[11] U. O. Hasani, "Analisis Kualitas Air Sungai Konaweha Provinsi Sulawesi Tenggara," Jurnal Ecogreen, vol. 2, pp. 123-129, 2017.

[12] L. Wei, Q. Zhou, C. Xie, J. Wang, and J. Li, "Bioaccumulation and biomagnification of heavy metals in three gorges reservoir and effect of biological factors," Huan jing ke xue= Huanjing kexue, vol. 37, pp. 325-334, 2016.

[13] E. Tovar-Sánchez, I. Hernández-Plata, M. S. Martínez, L. Valencia-Cuevas, and P. M. Galante, "Heavy Metal Pollution as a Biodiversity Threat," in Heavy Metals, ed: Intech Open, 2018.

[14] L. Li, X. Tian, X. Yu, and S. Dong, "Effects of acute and chronic heavy metal $(\mathrm{Cu}, \mathrm{Cd}$, and $\mathrm{Zn}$ ) exposure on sea cucumbers (Apostichopus japonicus)," Bio Med research international, vol. 2016, 2016.

[15] H. Hasmi, "PERANAN ANALISIS RISIKO KONSUMSI KERANG BERPLUMBUM DALAM MEMANAJEMEN RISIKO LINGKUNGAN PADA MASYARAKAT DI TELUK YOUTEFA," in SEMINAR NASIONAL, 2016.

[16] S. Basri, E. Bujawati, and M. Amansyah, "Analisis Risiko Kesehatan Lingkungan (Model Pengukuran Risiko Pencemaran Udara Terhadap Kesehatan)," Jurnal Kesehatan, vol. 7, 2014.

[17] D. Djafri, "Prinsip dan Metode Analisis Risiko Kesehatan Lingkungan," Jurnal Kesehatan Masyarakat Andalas, vol. 8, pp. 100-104, 2014.

[18] N. Nurfadillah, I. Praningtyas, S. Karina, and A. Perdana, "Analysis of heavy metals content $(\mathrm{Pb}, \mathrm{Hg}$ and $\mathrm{Cd})$ of Batissa violacea Lamarck in the coastal waters of Calang," in IOP Conference Series: Earth and Environmental Science, p. 012016, 2018.

[19] S. Dhanakumar, G. Solaraj, and R. Mohanraj, "Heavy metal partitioning in sediments and bioaccumulation in commercial fish species of three major reservoirs of river Cauvery delta region, India," Ecotoxicology and environmental safety, vol. 113, pp. 145-151, 2015.

[20] T. Sarkar, M. M. Alam, N. Parvin, Z. Fardous, A. Z. Chowdhury, S. Hossain, et al., "Assessment of heavy metals contamination and human health risk in shrimp collected from different farms and rivers at Khulna-Satkhira region, Bangladesh," Toxicology reports, vol. 3, pp. 346-350, 2016. 